\title{
The Influence of Social Network Structure on the Farmer Group Participation in Indonesia
}

\author{
Alia Bihrajihant Raya ${ }^{1}$ \\ ${ }^{1}$ Department of Socioeconomics of Agriculture, Faculty of Agriculture, Gadjah Mada University, Indonesia \\ Correspondence: Alia Bihrajihant Raya, Department of Socioeconomics of Agriculture, Faculty of Agriculture, \\ Gadjah Mada University, Jl. Flora 1 Bulaksumur, 55281 Yogyakarta, Indonesia. Tel: 62-274-56-3062. E-mail: \\ alia.bihrajihant.r@ugm.ac.id
}

$\begin{array}{lc}\text { Received: December 14, } 2015 & \text { Accepted: January 7, } 2016 \quad \text { Online Published: February 23, } 2016 \\ \text { doi:10.5539/ass.v12n3p119 } & \text { URL: http://dx.doi.org/10.5539/ass.v12n3p119 }\end{array}$

\begin{abstract}
The development of farmer groups in Indonesia is being stagnant because of the function of farmer group could not afford the needs of farmer group members. Participation of members is crucial to be assessed in order to promote the development of farmer group. To increase the participation of members, the social network structure between members and leaders should be taken into consideration. In this paper, the function of local institution leaders together with the function of farmer group leaders are measured in the social network structure. Through the graph of social network, it found that members will access information easily through the routine meeting in the local institution (neighborhood association) while the farmer group leaders are functioning as a legitimate of farmer group agenda. This paper suggests that the relationship between member and leader on the social network structure influences the member participation in the farmer group.
\end{abstract}

Keywords: farmer group, social network, local institution, participation

\section{Introduction}

Farmers' participation is one of the important factors on group sustainability in Indonesia. Such farmer groups are founded based on farmers who share similar needs, socioeconomics, and solidarity in order to improve the farmer member's activities. In fact, only around 8\% of farmer group has been categorized as an active farmer group which sustain the activity of farm production through high participation of member while in the same time only $30 \%$ of Indonesia farmers have joined as member of farmer group (Raya, 2014). In addition, active farmer groups mean it has a good group management structure and visible leadership so it could improve the economic conditions of each member and developed cooperation with third parties such as input providers and market production (Hermanto, 2010).

One of key that boost those farmers involve in a farmer group is the function of rural leader who share the experience on farming activities. According to Salifu et al. (2010) rural leaders are more likely to have a significant influence in encouraging participation in farmer group. Moreover, Raya (2014) found that communication between members and farmer group leaders could affect the commitment and satisfaction in which give a significant effect on the group performance and collective action. The pattern of communication and information exchange among farmers promotes collective behavior of farmers.

In order to mapping the pattern of interaction between each member of farmer group, social network analysis can be applied to understand how the social structure of relationships around a person, group or organization affects behaviors. Position of actor in the social network can demonstrate and predict the variety of actor's social behavior. The central position of actors in the network is related to the leadership effectiveness, individual influence and performance (Mehra et al., 2006). Structure of social network ties through high density on the group has also enhanced the group participation (Coleman, 1990). Mehra et al. (2006) found that centrality of actors influenced objective and subjective performance whereas Sparrowe et al. (2012) centrality affected to individual participation but structure of network could not affect to group participation.

Many important aspects of societal life in the community are organized as networks. The relationship among member of the community can be assessed by social network. A social network consists of a set of actors (nodes) and the relations (ties or edges) among these actors (Wasserman \& Faust, 1994). People's behavior is best 
predicted by the web of relationships in which they embedded rather than their motives, attitudes or demographic characteristic (Katz et al., 2005).

In this paper, there are three goals. The first is to elaborate the condition of common farmer group in the rural area of Indonesia. The second is to elaborate the position of members and leaders of local institution and farmer group in the social network. The third is to examine the influence of social network on members' participation in the farmer group.

\section{Literature Review}

Communication among members of the network reflects the state of relations between powerful members and ordinary members. Communication in the network shows how the community or groups are structured and developed (Kitetu, 2005). Social relationships are the outcome of the social process and interaction between organizational members and new knowledge could be created through the interaction of organizational information (Wen-Huang \& Wei Liu, 2007).

Since the establishment of social network structure is based on informal interactions between organizational members, it is essential to understand the function of organizational structure. Organizational structure is regarded as one of the forms of organizational control which aims to encourage organizational members to behave towards organizational goals (Cardinal, 2001). Organizational structure determines how information flows within the organization. Understanding the organizational structure of an organization tells the characteristic of an organization and the values it believes in. Organizational structures are sets of relations between the roles of an organization (Grossi, Royakkers, \& Dignum, 2007). Wen-Huang and Wei Liu (2007) concluded that organizational structure is a good predictor of organizational innovative capability however the influence of social structure in the community cannot be ignored either.

Groups are usually conceptualized as complex performance systems because they emerge from and sustain patterns of coordinated interdependencies among individual members. According to Forsyth (2010), groups as a system should recognize factors that set the stage of workgroups (i.e. historical processes), as well as processes in the group interaction such as group dynamics and performance as consequences that result from the group's participation. Salifu et al. (2012) declared that social action is closely related to social pressure, so group members tend to leave voluntarily when they know that they are not meeting requirements for participation.

Heemskerk and Wennink (2004) revealed that farmer groups are mostly informal (without formal membership and operating mainly at community level. FGs can either be based on existing group in community or specifically built. Once farmer groups are set up, meetings are important, and they should be interesting for every member, or farmer groups should find an alternative way to develop social interaction among members. According to Leeuwis and Aarts (2011), both formal communication through meetings and everyday communication have a critically significant connection to re-ordering social relationships.

According to Hermanto and Swastika (2011), farmer groups should function as a social group, but in Indonesia, many farmer groups function as task groups to reach a government task project. Regarding the function of social groups in the community of farmers, capital factors such as social capital, human capital, and economic capital should be taken into consideration to foster the dynamic process between groups and their members in order to increase their capacity to produce favorable outcomes (Topolsky, 1997). Turner and Reynolds (2010) conceptualized social groups as a number of individuals who internalize the same social category as a component of their group identification. In a social group, individuals affiliate with each other for many reasons, and the group emerges to stabilize the reciprocal form. In the reciprocal form between two or more individuals, a norm and trust, as is social capital, is needed to promote cooperation between individuals.

All forms of traditional culture of social groups are based on shared norms, which are used to achieve cooperation. Despite the fact social groups have a narrow range of trust (Fukuyama, 2001). Putnam (1993) defined social capital as the features of a social organization such as networks, norms, and trust to facilitate coordination and cooperation for mutual benefit. Davidsson and Honig (2003) emphasized that social capital related to the ability of actors to extract benefit from their social structures, networks, and membership. According to Rasmussen, Amstrong, and Chazdon (2011), the benefit can be organized into two poles: one that emphasizes the benefits of social capital for individuals, and another one that emphasizes the group benefit. Nahapiet and Ghoshal (1998) clarified that social capital is multidimensional and occurs at both the individual and the organizational levels, but Coleman (1988) emphasized that social capital is inherent in the structure of relations between actors and among actors.

Social network analysis is detecting and interpreting patterns of social ties among members of network (Nooy et 
al., 2011). A network consists of a graph and additional information on the vertices or the lines of the graph. A graph consists of a set of vertices and a set of lines or edges between pairs of vertices. Vertex (singular of vertices) is the smallest unit in a network while a line is a link between two vertices in a network. If two vertices are directly connected by line, the vertices are adjacent. A directed line is called an arc whereas an undirected line is an edge so that directed graph contains one or more arcs and undirected graph have not contained arc but edges. If every vertex is reachable to the any other vertex of the graph, it is called connected. The shortest paths link between two vertices is called geodesic. The length of geodesic from vertex $u$ to $v$ is a distance from vertex $u$ to $v$.

This paper contributes to the development of farmer groups literature in two considerations. First, the role of organizational structure of farmer group which is collaborate with the local institution in rural area of Indonesia. Second, the position of members toward leaders in the social network which give a significant influence on members' participation in farmer group.

\section{Materials and Methods}

Field research was carried out in 2013 on a farmer group in coastal sandy land area in the Kulon Progo District of the Yogyakarta Province. It was chosen based on the successful group and pioneer farmer group in costal sandy land area. All members of farmer group were interviewed. To determine the membership network, the roster method was used (Butt, 2008). Respondents were asked the question: "To whom do you go for asking information among the members including leaders of the farmer group?"

Each respondent was free to choose as many names of members on a list as desired. Then, the data was analyzed by Pajek 3.15, which measures the size, density, distance, degree, and cliques of the network. The data of distance to RT heads and distance to FG leaders, and position of member in the organization: number of in-degree and number of out-degree are used as explanatory variables.

The members' participation was measured by the proportion of chilies sold through farmer group (Y). There are ten independent variables: age (X1), education (X2), number of household members (X3), land holding (X4), remittance received (X5), engagement in an off-farm job (X6), distance to the neighborhood association heads (X7), distance from the FG leaders (X8), number of in-degree on the social network (X9), and number of out-degree on the social network (X10).

To examine the influence of independent variables towards the members' participation of chili sold through farmer group, Tobit regression was used because the dependent variable is truncated at selling $100 \%$ of the chilies via farmer group.

Table 1. Descriptive statistics of explanatory and dependent variable of farmer group

\begin{tabular}{cccccc}
\hline Variable & N & Minimum & Maximum & Mean & Std Dev \\
\hline Age & 60 & 24 & 74 & 43.09 & 10.47 \\
Education & 60 & 0 & 12 & 9.27 & 2.76 \\
No. of household members & 60 & 1 & 9 & 3.78 & 1.73 \\
Land holdings & 60 & 0.05 & 1.49 & 0.49 & 0.35 \\
Have an off-farm job* & 60 & 0 & 1 & 0.25 & 0.44 \\
Receiving remittance* & 60 & 0 & 1 & 0.11 & 0.31 \\
Distance to RT heads & 60 & 0 & 2 & 1.11 & 0.31 \\
Distance to FG leaders & 60 & 0 & 2 & 0.98 & 0.30 \\
In-degree & 60 & 2 & 66 & 11.12 & 10.38 \\
Out-degree & 60 & 4 & 21 & 10.45 & 3.64 \\
Participation on collective selling & 60 & 67 & 100 & 95 & 8.95 \\
\hline
\end{tabular}

Source: Data Analysis, 2015 


\section{Results and Discussion}

\subsection{Condition of Local Institution in Rural Area of Indonesia}

In the rural area of Indonesia has more than 70,000 village operates with the single administrative structure. Based on Government Regulation No. 72/2005, a village is under the governance which consists of a village council (BPD). The village government is led by a village head and administrators such as a secretary, administrative section head, economic and development section head, finance section head, and community welfare section head. The village council consists of representatives, such as RT (neighborhood association) heads, customary group heads, religious heads, and other leaders of social groups from the village. Based on the Decree of Ministry of Home Affairs No 5/2007, social groups at the village level include LPMD (Village Group of Empowerment Activities), PKK (Village Group of Women Empowerment), Karang Taruna (Youth Group Activities), RT (Neighborhood Association) and customary groups. The relationship among these groups is consultative, coordinative and considered to be a partnership.

In this paper, among several social groups that exist in the village, only RT as a solidarity unit or neighborhood association, as a territory unit, will be considered. The RT has a role in organizing the villagers because its existence is based on the housing territory. Every RT consists of 20-35 households and is chaired by one leader who is assisted by a secretary and treasurer. Regular RT meetings are held monthly. The RT acts as a supporting agent for sharing information from and to villagers. The RT head records the villagers' administration documents and determines such information as the number of poor households and the number of households that should receive rice subsidies. The RT head mobilizes members whenever gotong royong (working together) for public purposes is needed.

In addition, in rural areas, farmer groups are also considered to be a social group, which is independent from the village social groups that are governed by the Ministry of Home Affairs. The farmer group is supervised by the Ministry of Agriculture, based on the decree of the Ministry of Agriculture, No. 273/Kpts/Ot.160/4/2007. The formation of the farmer groups is based on the necessity of farmers, even though the groups are primarily formed by external initiators to gain government subsidies.

\subsection{Condition of Farmer Group in Indonesia}

Agriculture Ministerial Decree No. 82/Permentan/OT.140/8/2013 mentions that in Indonesia, many farmers still do not belong to any farmer group, which has resulted in extension officers facing difficulty in empowering farmers' capacity and capability. As a result, the agriculture ministry proclaimed to establish many grassroots farmer groups by making use of the former social groups in the community. For instance, farmer groups should be established with the smallest unit of a community such as a RT (neighborhood association), which has 20-35 households or any other local institutions which were appeared earlier.

Indonesia has made use of farmer groups as one approach to develop rural communities since the program of Balai Pendidikan Masyarakat Desa (Community Village Council of Education) started on 1948. The policy of rural development in the 'group' means that the government should assist in the foundation of farmer groups. Then, farmers were instructed on what to do and were given incentives through the provision of cheap credit to follow these instructions. As program of farmer group development was initially initiated, Indonesia government instructed farmers to increase only rice production even though other commodities have also been important (Resosudarmo \& Yamazaki, 2011). Even though recently there are seven commodities becomes a target of high production, such as rice, corn, soybean, sugar, chili, onion, and meat but still there are not many farmer groups with active members that are functioning regularly. In fact, the focus of farmer group activities in Indonesia are mostly only on the technological adoption (Muktasam, 2001).

Based on the statistical data of agricultural human resources and farmer Institutions (2013), revealed that from 2011 until 2013, there were an increasing number of farmer groups in Indonesia, with around 18,367 new groups. However, the increased number of farmer groups has not been followed by an increased number of qualified farmer groups, because much of the purpose of establishing farmer groups is only for accessing government subsidies. So that, the function of farmer groups is limited on accessing subsidies and succeed the government or donor project. The organizational structure of farmer groups is independent from the existing social organization in the rural area (village). This type of farmer groups is fragile and tend not to be sustained.

\subsection{Best Practice Farmer Group Organization in Indonesia}

In this paper will introduce the best practice farmer group which the function of RT head is included on the organizational structure of farmer group. The RT head is given an extended span of control from the farmer group leaders in order to disseminate the information and organize the members. Meanwhile, the main function 
of the RT is to support the village government tasks while an additional function involves supporting the farmer group tasks.

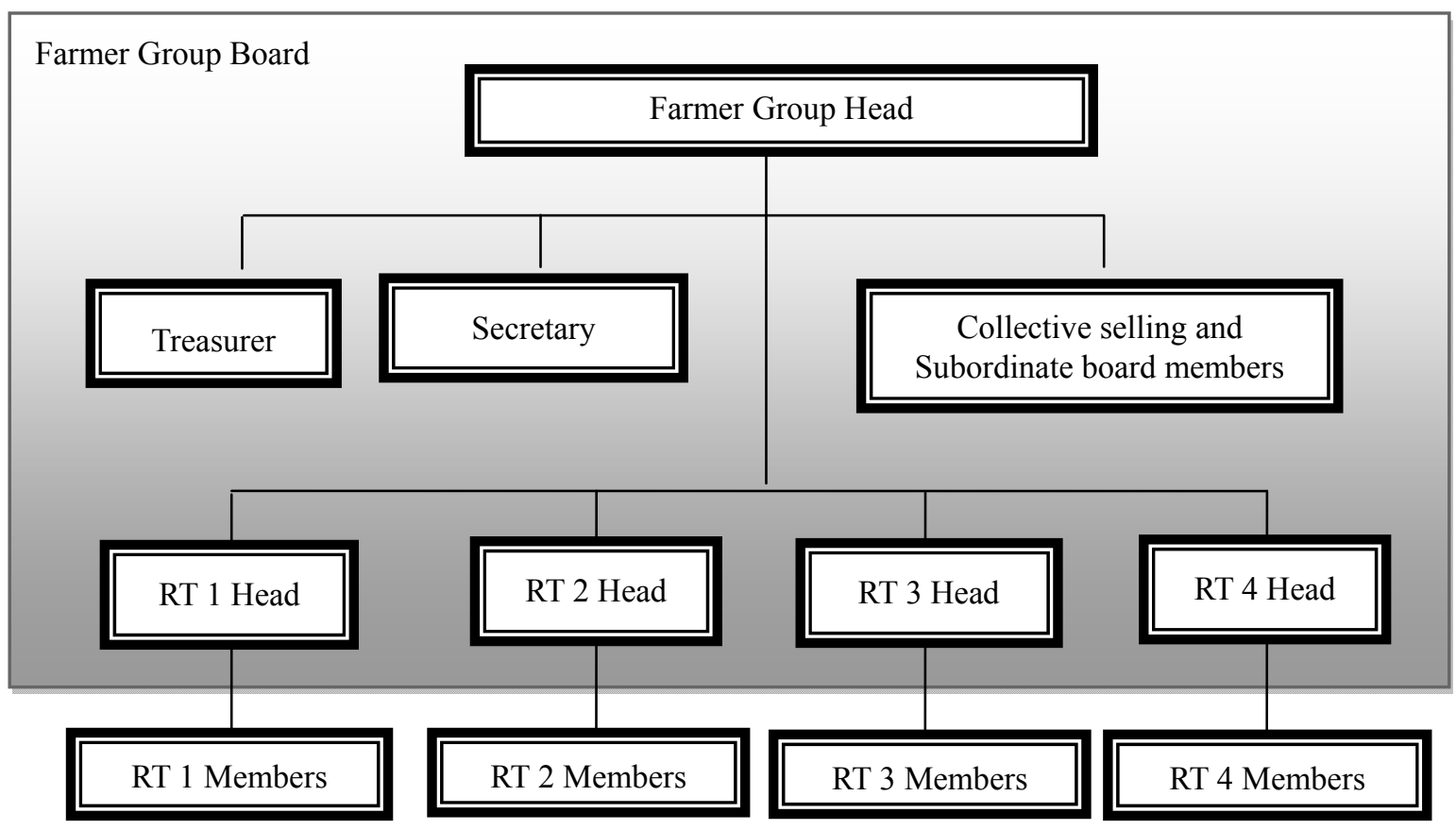

Figure 1. The best practice farmer group board

Based on the Figure 1 Farmer group is leaded by a head and is helped by one treasurer, one secretary, three subordinate board members and four RT heads (RT 1, RT 2, RT 3 and RT 4) which are integrating the local institution in the rural area. Subordinate board members are person in charge of collective marketing by farmer group, and they coordinate with the other members as laborers during the event. The collective marketing section and subordinate board members are not in charge on the decision making, only the farmer group head, treasurer, and secretary are considered as FG leaders.

Residents of the village who want to be member of farmer group should contact the RT head. He or she will be a member of sub-group on his/her RT territory and automatically become a member of farmer group. Each member is required to participate in collective activities such as working together for public purpose, attending the group meeting, obeying the rules of chili planting duration, selling the chili product at least $80 \%$ of total product to the farmer group and working at collective marketing events. Social punishment such as ostracism will be endured by a farmer who is absent from collective actions. The farmer who breaks the rules of chili planting duration will get sanction from the group. In accordance with that, farmer group has facilitated all members equally.

Communication takes place among farmer group leaders and members at routine meetings every 35 days. Furthermore, in order to disseminate information quickly, farmer group leaders delegate RT heads to circulate news to all members. Each RT head has the responsibility of delivering information from the farmer group to the RT members through meetings and interpersonal communication.

The activity of collective selling is led by the collective marketing head. However, participation from all members are shown through scheduled on shifts and expected to contribute to the activities, which consist of scaling, packaging and placing the chilies on the truck. On the event of collective marketing, approximately 30 members will take turns in working in the collective marketing activities.

\subsection{The Social Network Structure in the Best Practice Farmer Group}

In this farmer group, the mutual action among members has been triggered by the existence of RT meetings, FG meetings and gotong royong (collective action). RT meetings are held on the basis of the RT territory. Every RT has its own meeting, which is usually held every 35 days. The existence of RT meetings provides an opportunity for RT members to become connected with each other. Furthermore, in the case of the FG meeting, which is also held every 35 days, it provides an opportunity for all members to become connected with the FG leaders. 
Meanwhile, the labor exchange in gotong royong produces the reciprocal ties among members, because every member should provide the reciprocal exchange of harvesting labor.

Table 2. Distance between members and RT heads in the best practice farmer group

\begin{tabular}{ccccccccc}
\hline \multirow{2}{*}{ Distance } & \multicolumn{2}{c}{ RT 1 Head } & \multicolumn{2}{c}{ RT 2 Head } & \multicolumn{2}{c}{ RT 3 Head } & \multicolumn{2}{c}{ RT 4 Head } \\
\cline { 2 - 9 } & FG* & RT & FG & RT & FG & RT & FG & RT \\
\hline Ego (RT Head) & 1 & 1 & 1 & 1 & 1 & 1 & 1 & 1 \\
Distance of 1 & 28 & 24 & 23 & 19 & 23 & 16 & 24 & 17 \\
Distance of 2 & 54 & 1 & 61 & 4 & 62 & 1 & 60 & 0 \\
Distance of 3 & 3 & 0 & 1 & 0 & 0 & 0 & 1 & 0 \\
Total members & 86 & 26 & 86 & 24 & 86 & 18 & 86 & 18 \\
\hline
\end{tabular}

Note: FG is the position of RT head in the Farmer Group

Source: Primary Data Analysis, 2015

Table 2 shows that most RT members have a distance of 1 to the RT heads. It can be concluded that RT heads are focal person in the RT territory. However, the RT head functions only in his territory; the functioning of FG leaders will be mentioned later. Furthermore, in the RT heads ego-centered network, as far as the ties between RT heads and distance of 1 are concerned, the reciprocal ties are dominant. The percentages of reciprocal ties among the ties with each RT members are as follows: RT 1, 82\%; RT 2, 80\%; RT 3, 92\%; and RT 4,82\%. It means, the cliques are developed in each RT territory. The number of cliques on each RT head ego-centered network is as follows, RT 1 head, 47; RT 2 head, 49; RT 3 head, 45 and RT 4 head, 50. It shows that the cliques are developed in each RT territory.
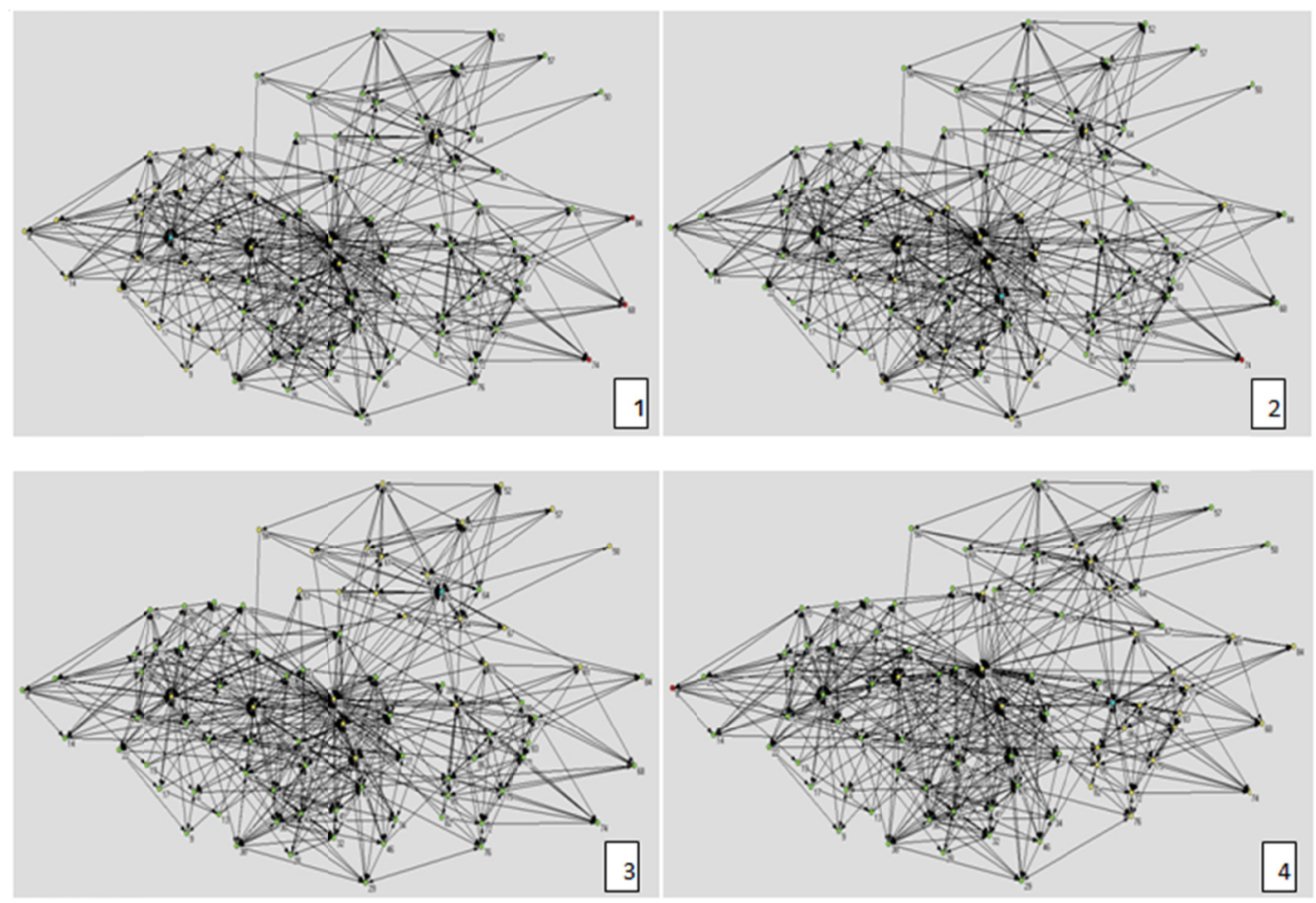

Note of Figure

$1=$ RT 1 (RT head's node is 12 )

$3=$ RT 3 (RT head's node is 65)

$2=$ RT 2 (RT head's node is 79)

$4=$ RT 4 (RT head's node is 78)

Figure 2. Ego-centered network of RT heads in farmer group 
As shown on Figure 2 social network is dominated by reciprocal ties and contains many cliques. Members are not only concerned about seeking the information of FG activities from the important nodes (RT heads), but also conducting reciprocal activities on chili farming together with members of RT. The reciprocal ties are formed by some activities in the RT territory, such as RT meetings and gotong royong. The RT head has the task of delivering and controlling the flow of the farmer group information. The RT's routine meetings are a place where the RT head can connect with the RT members. Additionally, the activity of gotong royong which is managed under the RT territory, establishes reciprocal ties among RT members.

Considering the leaders of farmer group, it consists of the FG head, treasurer, secretary and three subordinate members. As mentioned before, subordinate board members are not in charge on the decision making so only FG head, treasurer and CM head are considered as FG leaders. Because of the head does not execute the leader's task alone; there are two other persons (secretary and treasurer) that support his tasks in a supplemental function. In this sense, their role should be taken into consideration as far as leadership is concerned. The number of neighbors of at least one of the FG leaders is provided in the fourth column in Table 3.

Table 3. Distance between members and leaders in the farmer group

\begin{tabular}{ccccc}
\hline Distance & FG Head (48) & Treasurer (49) & CM Head (16) & FG Leaders \\
\hline Ego & 1 & 1 & 1 & 3 \\
Distance of 1 & 66 & 37 & 38 & 76 \\
Distance of 2 & 19 & 48 & 47 & 7 \\
Total Members & 86 & 86 & 86 & 86 \\
\hline
\end{tabular}

Source: Primary Data Analysis, 2015

Table 3 shows that 76 members are neighbors of at least one FG leader. If one person cannot reach the FG head, he will try to connect directly to the other leaders. As a result, $91.56 \%$ of members are neighbors of FG leaders. In the RT level, members tend to seek information on the RT heads as a nearest reliable person, whereas at the FG level, they can easily connect with the FG leaders. Members can also connect with FG leaders directly in the periodic FG meetings. In addition, each FG leader is also a member of a certain RT so that the ties between the members and FG leaders tend to be smoothly established.
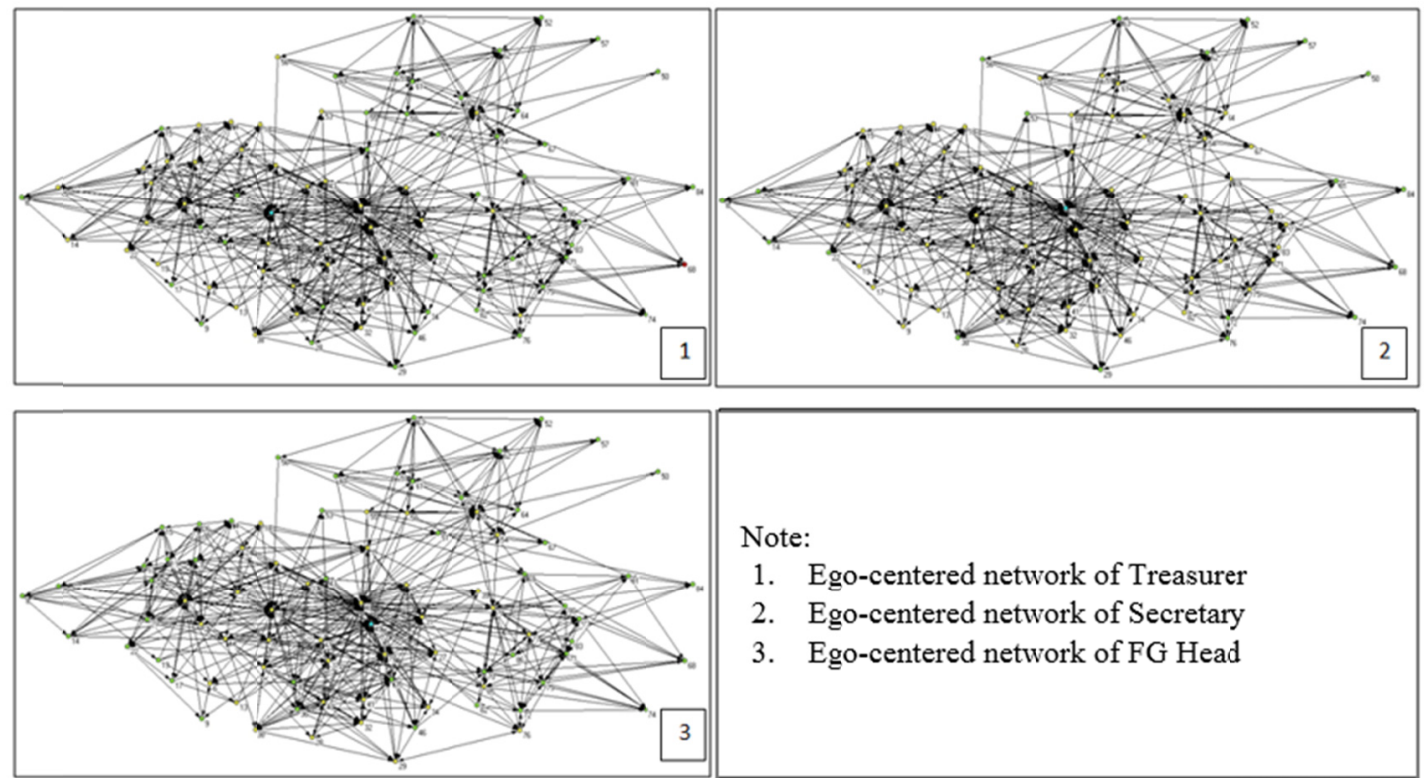

Note:

1. Ego-centered network of Treasurer

2. Ego-centered network of Secretary

3. Ego-centered network of FG Head

Figure 2. Ego-centered network of farmer group leaders 


\subsection{The Influence of Social Network on the Farmer Group Participation}

A Tobit regression indicates that the participation on the farmer group which was measured by the proportion of selling through farmer group is significantly positive, influenced by age, land holding, and distance to the RT heads. While, distance to the FG leaders give significantly negative influence.

Table 4. Tobit regression the influence of social network on farmer group participation

\begin{tabular}{lccc}
\hline \multirow{2}{*}{ Independent Variable } & \multicolumn{3}{c}{ Participation } \\
\cline { 2 - 4 } Characteristics of households & Coeff & Rob.SE & Sig \\
Age & 0,283 & 0,167 & $0.096^{*}$ \\
Education & 0,573 & 0,542 & 0,295 \\
Number of household member & $-0,638$ & 0,889 & 0,476 \\
Land holding & 0,001 & 0,001 & $0.041^{* *}$ \\
Remittance & $-2,158$ & 3,966 & 0,589 \\
Off-farm & $-3,079$ & 4,271 & 0,474 \\
Characteristics of organization & & & \\
Distance to Leaders & & & $0.057^{*}$ \\
Distance to RT heads & 6,586 & 3,381 & $0.041^{* *}$ \\
Distance to FG leaders & $-12,185$ & 5,804 & \\
Position of member in FG & & & 0,377 \\
In-degree & 0,358 & 0,402 & 0,929 \\
Out-degree & $-0,044$ & 0,493 & $0.000^{* * *}$ \\
Constanta & 80,110 & 11,373 & \\
/sigma & & & \\
Number of Observation & 9,877 & 1,028 & \\
Prob $>$ F & 60 & & \\
F (10, 50) & 0,018 & & \\
Log Pseudo likelihood & 2,45 & & \\
Pseudo R & & & \\
\hline Souce: Pring & -151.92 & & \\
\hline
\end{tabular}

Source: Primary Data Analysis, 2015

In the Farmer Group, the position of the RT heads is as important as the FG leaders for the farmer group activities. Most of members have a distance of 1 with FG leaders and their own RT heads. The distance to RT heads influences the participation on selling chili product on farmer group positively, while the distance to FG leaders influences it negatively. The positive influence of the distance of RT heads should be explained by the activity of RT 4's members, some of whom are working as smallholder chili traders. They should fulfill the quota of chilies ordered by intermediate traders so they should collect chilies from neighbors and sell their own chili product to fill the quota. This situation was concerning to FG leaders, so they adjust the number of participation by selling product from $100 \%$ to more than $80 \%$, The RT 4 head himself shows his support to those sub-intermediate traders by selling some portion of his product to them. Those sub-intermediate traders have a distance of 1 with their RT heads. As a result, the statistical result shows that the closer to RT heads an individual is, the fewer chilies sold by collective marketing.

In the case of distance to FG leaders, most farmers have a distance of 1 from FG leaders, while a few of them have a distance of 2 from the FG leaders. Some of the farmers who have distance of 2 from the FG leaders are the members who work as sub-intermediate traders in RT 4. Their activity of selling fewer chilies outside the 
group generates a feeling of dissimilarity on the group participation, because the management of the FG is concerned with evenness, conformity, and equality. So that, members who behave differently will make a distance to the FG leaders while leaders should understand this such kind of situation then leaders should create a mechanism to get near to members. According to Raya (2014), farmer group leaders should inspire members to contribute more by internalizing the value of farmer group. The transformational leadership of farmer group leaders in Indonesia are important issues which should be taken into consideration to implement it because members need to be motivated, inspired, and encouraged to have a sense of belonging of farmer group.

In the analysis was found that older farmers tend to participate higher by sell a greater proportion of chilies product to the farmer group. The farmer group is managed and strongly supported by the community network as seen on Figure 2 and Figure 3. The elders are expected to follow the organization's rules, based on the expectation among community members; at the same time, elders respect and preserve the rules to keep the community organized. This finding is accordance with the concept of social hierarchy in Java, Indonesia which is stated by Koentjaraningrat. Elder people will preserve the local norms in order to harmonize the community culture. Since the farmer groups are developed in the village or even hamlet so that the function of farmer group should fuse with the local institution to be sustained and maturated.

On the other hand, holding more land can be regarded as an economic condition. The farmers who have more land are better able to cultivate side crops, like bitter melon and eggplant, in the edge area of chili farming. By cultivating side crops, they can earn cash money to ease their needs for immediate cash like daily needs, paying tuition fees, medical treatment, and especially for agriculture laborer wages. Thus, their participation will be higher because they can sell a higher percentage of their chili product through farmer group without any hesitancy.

\section{Conclusion}

This paper has addressed the importance consideration on the different type of farmer group leads the different participation. The common farmer group which built by external agent without involving the local institution in the village is fragile because of disintegrated function of each institution in the village. The local institution such as neighborhood association which has duty to support villagers on daily activities could be use as integrated institution with the function of farmer group. It is because the member of farmer group is also the member of neighborhood association.

The findings show that RT territory is a baseline for each activity on the farmer group and RT heads are also focal person in the community. The ties among RT members have been developed by RTs based activities: RT meetings and customary groups of exchange labors (gotong royong). Through routine meetings, they can meet periodically while the ties among them can also be established. In addition, farmer group leaders are also RT members so that through participation in the RT based activities, they contribute to the higher possibility of becoming connected with FG members at the RT level. In addition, the activity of gotong royong, which requires the reciprocity of each gotong royong member, they establish the reciprocal ties among RT members. As a result, RT activities affect the pattern of networks and an interlocking friendship network emerges. As a result, the interaction of members in the organization is maintained by the existence of periodical meeting, rules and norms.

In the best practice farmer group, the economic condition contributes the higher participation on farmer group as similar as common farmer group. Distinct from common farmer group, the relationship between members and farmer group leader and local leaders in a best practice farmer group have a significant effect on farmer group participation. Support from local institution leader could be legitimated the activities in the rural area so that the integration between activities in the farmer group and the rural area strengthen the achievement of farmer group and rural goals. Synergizing the rural area goals and farmer groups agenda would promote the behavior of each farmer to access group facilities and information equally.

\section{Acknowledgements}

The author would like to thanks to Professor Takenori Matsumoto and Professor Takeshi Sakurai, The University of Tokyo, for the valuable comments on the process of writing this paper.

\section{References}

Butts, C. T. (2008). Social network analysis: A methodological introduction. Asian Journal of Social Psychology, 11, 13-41. http://dx.doi.org/10.1111/j.1467-839X.2007.00241.x

Cardinal, L. B. (2001). Technological innovation in the pharmaceutical industry: the use of organizational control in managing research and development. Organization Science, 12(1), 19-36. 
Coleman, J. S. (1998). Social capital in the creation of human capital. American Journal of Sociology, 94 , 95-120. Retrieved from http://www.jstor.org/stable/2780243

Davidsson, P., \& Honig, B. (2003). The role of social and human capital among nascent entrepreneurs. Journal of Business Venturing, 18, 301-331. http://dx.doi.org/10.1016/S0883-9026(02)00097-6

Forsyth, D. R. (2010). Group Dynamics. Wadsworth Cengage Learning, USA.

Fukuyama, F. (2010). Social capital, civil society and development. Third World Quarterly, 22(1), 7-20. http://dx.doi.org/10.1080/713701144.

Grossi, D., Royakkers, L., \& Dignum, F. P. M. (2007). Organizational Structure and Responsibility. An Analysis in a Dynamic Logic of Organized Collective Agency. Journal of Artificial Intelligence \& Law, 15, 223-249.

Heemskerk, W., \& Wennink, B. (2004). Building Social Capital for Agricultural Innovation: Experiences with farmer groups in Sub-Saharan Africa. Royal Tropical Institute (KIT), Amsterdam.

Hermanto, \& Swastika, D. K. S. (2011). [Peningkatan kelompok tani: Langkah awal kesejahteraan petani. Strengthening farmers group: Improving the welfare of farmers first step]. Analisis Kebijakan Pertanian, 9, 371-390. Retrieved from http://pustaka.litbang.deptan.go.id

Hermanto. (2010). Pengembangan Kelembagaan Petani. Opini, Bangka Pos, 16 Januari 2010.

Katz, N., Lazer, D., Arrow, H., \& Contractor, N. (2004). Network Theory and Small Group. Small Group Research, 35(3), 307-332. http://dx.doi.org/10.1177/1046496404264941

Kitetu, C. W. (2005). Farmer Groups as a way of mobilizing citizen participation in development: An example from Kenya. Presented at the 11 th general assembly. Maputo. Retrieved from http://ageconsearch.zzzumn.edu/bitstream/155472/2/3_Murage.pdf.

Leeuwis, C., \& Aarts, N. (2011). Rethinking communication in Innovation Processes: Creating space for change in complex system. Journal of Agricultural Education and Extension, 17(1), 21-36. http://dx.doi.org/10.1080/1389224X.2011.536344.

Mehra, A., Andrea, L. D., \& Daniel, J. B. (2006). The Social Network Ties of Group Leaders: Implication for Group Performance and Leader Reputation. Organization Science, 17, 64-67. http://dx.doi.org/10.1287/orsc. 1050.0158

Muktasam, A. (2001). A longitudinal study of group roles in Indonesia rural development: an analysis of policy formulation, implementation and learning outcomes (Unpublished doctoral dissertation). School of Natural and Rural Systems Management. The University of Queensland, Australia.

Nahapiet, J., \& Ghosal, S. (1998). Social capital, intellectual capital, and the organizational advantage. Academy of Management Review, 23(2), 242-266. Retrieved from http://www.jstor.org/stable/259373

Nooy, W., Mvrar, A., \& Batagelj, V. (2011). Exploratory Social Network Analysis with Pajek: Revised and expanded second edition. New York: Cambridge University.

Putnam, R. (2000). Social Capital: Measurement and consequences. Retrieved from https://www1.oecd.org/edu/innovation-education/1825848.pdf

Rasmussen, C. M., Armstrong, J., \& Chazdon, S. A. (2011). Bridging brown county: captivating social capital as a means to community change. Journal of Leadership Education, 10(1), 63-81. http://dx.doi.org/10.12806/V10/11/RF4

Raya, A. B. (2014). Farmer Group Performance of Chili Collective Marketing on Sandy Land Area of Yogyakarta Province Indonesia. Asian Social Science, 10(10), 1-12. http://dx.doi.org/10.5539/ass. v10n10p1

Raya, A. B. (2014). A Comparison of the function of leader-member exchange in two neighboring farmer groups in a sandy land area of Yogyakarta Province, Indonesia. Asian Social Science, 10(12), 21-34. http://dx.doi.org/10.5539/ass.v10n12p21.

Resosudarmo, B., \& Yamazaki, S. (2011). Training and Visit (T\&V) Extension vs. Farmer field School: The Indonesian Experience. Working Papers in Trade and Development. ANU College of Asia and the Pacific. Retrieved from https://ccep.crawford.anu.edu.au/acde/publications/publish/papers/wp2011/ wp_econ_2011_01.pdf

Salifu, A., Francesconi, G. N., \& Kolavalli, S. (2010). A Review of Collective Action in Rural Ghana. IFPRI 
Discussion Paper 00998. Retrieved from http://core.ac.uk/download/files/153/6227518.pdf

Salifu, A., Lee Funk, R., Keefe, M., \& Kolavalli, S. (2012). Farmer Based Organization in Ghana. Working Paper Ghana Strategy Support Program. IFPRI. Retrieved from http://citeseerx.ist.psu.edu/viewdoc/ download?doi=10.1.1.278.7883\&rep=rep1\&type=pdf

Topolsky, J. (1997). On target, on task, on reflection: the culture of learning communities. Plenary of the International Conference Community Development Society, Athens, Georgia, USA.

Turner, J. C., \& Reynolds, K. J. (2010). Self categorization theory. In P. A. M. Van Lange, A. W. Kruglanski, \& E. T. Higgins (Eds.), Handbook of Theories of Social Psychology. SAGE.

Volmer, J., Niessen, C., Spurk, D., Linz, A., \& Abele, A. E. (2011). Reciprocal relationship between LMX and job satisfaction: a cross-lagged analysis. Applied Psychology: An international review, 60(4), 522-545. http://dx.doi.org/10.1111/j.464-0597.2011.00446.x

Wahyuni, S. (2003). Kinerja kelompok tani dalam sistem usaha tani padi dan metode pemberdayaannya. $J$. Litbang Pertanian, 22. Retrieved from http://pustaka.litbang.deptan.go.id/publikasi/p3221031.pdf

Wahyuni, S. (2003). Kinerja kelompok tani dalam sistem usaha tani padi dan metode pemberdayaannya. $J$. Litbang Pertanian, 22. Retrieved from http://pustaka.litbang.deptan.go.id/publikasi/p3221031.pdf

Wang, H., Law, K. S., Hackett, R. D., Wang, D., \& Chen, Z. X. (2005). Leader-member exchange as a mediator of the relationship between transformational leadership and followers' performance and organizational citizenship behavior. Acad. Manage. J., 48, 420-432. http://dx.doi.org/10.5465/AMJ. 2005.17407908

Wasserman, S., \& Faust, K. (1994). Social network analysis: Methods and applications. New York: Cambridge University.

Wen-Huang, P., \& Wei-Liu, C. (2007). The Impact of Organizational Structure and Social Structure on Organizational Structure Knowledge Creation: A Conceptual Framework. Retrieved from http://www.isu.edu.tw/upload/28/3/29520/paper/9601/960102.pdf

\section{Copyrights}

Copyright for this article is retained by the author(s), with first publication rights granted to the journal.

This is an open-access article distributed under the terms and conditions of the Creative Commons Attribution license (http://creativecommons.org/licenses/by/3.0/). 